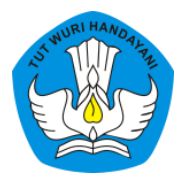

\title{
PENERAPAN MEDIA KONVERSI PECAHAN UNTUK MENINGKATKAN HASIL PEMBELAJARAN MATEMATIKA DI SEKOLAH DASAR
}

\author{
Roni Rahmawanto \\ Sekolah Dasar Negeri Ngentak Bantul, Indonesia \\ Email: roni27121986@yahoo.com
}

Published: Juli 30, 2020

Article Url: https:/ / ojsdikdas.kemdikbud.go.id/index.php/didaktika/article/view/126

\begin{abstract}
The purpose of this research is to improve Mathematics learning in grade $V$ students using Fraction Conversion media. Based on preliminary observations, the teacher discovers the difficulties experienced by V grade in 2018/2019 during Mathematics learning. The results of the final semester 1 assessment obtained the average value of students in basic competency 1, namely 55 and basic competency 2 , namely 47. Classroom action research was implemented to improve the process and results of learning Mathematics through the use of Fraction Conversion media. Learning material is focused on equations, addition, subtraction, multiplication, and fraction distribution. Learning outcomes data were collected using tests. Whereas, student activity data and mathematics learning skills through observation when learning takes place. Data analysis using quantitative and qualitative descriptive. The results of data analysis showed that the completeness of student mathematics learning increased from $71 \%$ to $87 \%$. In addition, the activities and skills of students also increased due to the use of Fraction Conversion media. The conclusion is that the use of Fraction Conversion Media can improve the cognitive and psychomotor learning outcomes and processes of fifth grade students at Ngentak Elementary School.
\end{abstract}

Keywords:Fraction Conversion Media, Learning Outcomes, Mathematics 


\begin{abstract}
Abstrak
Tujuan dalam penelitian ini adalah meningkatkan pembelajaran Matematika siswa kelas V menggunakan media Konversi Pecahan. Berdasarkan pengamatan awal, guru menemukan kesulitan yang dialami oleh siswa kelas $V$ tahun 2018/2019 saat pembelajaran Matematika. Hasil penilaian akhir semester 1 didapatkan nilai rata-rata siswa pada kompetensi dasar 1 yaitu 55 dan kompetensi dasar 2 yaitu 47. Penelitian tindakan kelas diimplementasikan untuk meningkatkan proses dan hasil pembelajaran Matematika melalui penggunaan media Konversi Pecahan. Materi pembelajaran difokuskan pada persamaan, penjumlahan, pengurangan, perkalian, dan pembagian pecahan. Data hasil pembelajaran dikumpulkan menggunakan tes. Sedangkan, data aktivitas siwa dan ketrampilan pembelajaran matematika dengan melalui observasi saat pembelajaran berlangsung. Analisis data menggunakan deskriptif kuantitatif dan kualitatif. Hasil analisis data menunjukkan ketuntasan pembelajaran matematika siswa meningkat dari $71 \%$ menjadi $87 \%$. Di samping itu, aktivitas dan ketrampilan siswa juga mengalami peningkatan akibat penggunaan media Konversi Pecahan. Simpulannya yaitu bahwa penggunaan Media Konversi Pecahan dapat meningkatkan proses dan hasil belajar kognitif dan psikomotorik siswa kelas V SDN Ngentak .
\end{abstract}

Keywords: Media Konversi Pecahan, Hasil Belajar, Matematika

\title{
A. Pendahuluan
}

Pengetahuan, teknologi, dan komunikasi terus berkembang. Indonesia telah memasuki era industri 4.0. Dibutuhkan sumber daya manusia yang kreatif, inovatif, dan terampil untuk menghadapinya. Hal ini menjadi tantangan bagi guru untuk meningkatkan kualitas pembelajaran di kelas. Guru dituntut untuk menciptakan pembelajaran yang dapat melibatkan siswa secara aktif dalam pembelajaran. Hal ini sesuai dengan tuntutan abad 21 untuk melahirkan manusia yang mempunyai cara berpikir kritis, kemampuan bekerja sama, mempunyai daya kreativitas, dan mempunyai kemampuan berkomunikasi yang baik. Oleh karena itu, pembelajaran yang baik harus menekankan pada aktivitas siswa.

Penerapan kurikulum 2013, membantu guru dalam menciptakan suasana belajar yang aktif, kreatif, dan menyenangkan. Guru harus menggunakan berbagai strategi, metode, dan media yang sesuai dengan karakteristik muatan pelajaran. Penggunaan berbagai strategi, metode, dan media dalam pembelajaran akan menciptakan suasana kelas yang mendukung 
dalam perkembangan siswa. Dengan demikian, siswa diharapkan dapat meningkatkan sikap, pengetahuan dan keterampilan yang dimilikinya.

Dari hasil observasi saat pembelajaran, sebagian besar siswa kelas V SD Ngentak yang berjumlah 16 anak mengalami kesulitan dalam materi pembelajaran Matematika. Hasil ulangan semester I menunjukkan hanya 5 siswa yang mendapatkan nilai di atas Kriteria Ketuntasan Minimal (KKM) yaitu 75. Banyaknya siswa yang memperoleh nilai di bawah KKM, menunjukkan kesulitan siswa dalam mempelajari materi pelajaran Matematika.

Akibat dari kesulitan tersebut, semangat siswa untuk mempelajari materi pelajaran Matematika menjadi rendah. Siswa yang kesulitan tampak kurang antusias dalam belajar. Siswa menjadi tidak memperhatikan dan berkeluh kesah saat menemui soal yang sulit. Guru berusaha memotivasi siswa dengan membimbing dan mendampingi siswa saat mengerjakan soal. Usaha guru tersebut tampak belum berhasil karena masih banyaknya siswa yang menunjukkan sikap kurang bersemangat.

Dari hasil diskusi dengan teman sejawat ditemukan sebab dari permasalahan tersebut yaitu tidak digunakannya media dalam kegiatan pembelajaran. Tidak digunakannya media dalam kegiatan pembelajaran menyulitkan siswa dalam memahami materi pelajaran. Dalam mempelajari materi pelajaran, siswa sekolah dasar masih berada dalam tahap berpikir operasional konkret. Siswa harus dibantu dengan benda nyata untuk memudahkannya dalam memahami materi pembelajaran yang bersifat abstrak.

Tidak digunakannya media dalam kegiatan pembelajaran disebabkan karena tidak lengkapnya media yang dimiliki SD Ngentak. Media pembelajaran yang dimiliki SD Ngentak sangat sedikit dan banyak juga media yang sudah rusak. Salah satu media yang tidak dimiliki SD Ngentak yaitu media tentang pecahan. Padahal materi pecahan adalah materi yang dianggap sulit oleh siswa sehingga ketersediaan media tersebut sangat penting. Kondisi semacam ini akan sangat merugikan siswa. Dengan tidak adanya media pembelajaran, siswa kesulitan dalam memahami materi pembelajaran yang diajarkan guru. 
Melihat deskripsi permasalahan di atas, guru meyakini bahwa tidak adanya alat peraga bukan merupakan suatu hambatan. Siswa harus tetap terpenuhi hak belajarnya. Oleh karena itu, guru berusaha memecahkan permasalahan tersebut dengan membuat sendiri media pembelajaran Matematika materi pecahan. Media tersebut dinamakan Media Konversi Pecahan. Media Konversi Pecahan akan membantu siswa dalam memahami besar kecilnya nilai pecahan dan perbandingan nilai pecahan dengan jenis pecahan yang lain. Media ini juga membantu siswa dalam memahami materi penjumlahan, pengurangan, perkalian, dan pembagian pecahan.

Dalam melaksanakan penelitian ini, masalah dirumuskan dengan beberapa pertanyaan yaitu bagaimanakah penggunaan Media Konversi Pecahan pada materi pecahan pada siswa kelas V Sekolah Dasar serta bagaimanakah penggunaan Media Konversi Pecahan dapat meningkatkan hasil belajar siswa kelas V Sekolah Dasar.

Sementara itu, tujuan dalam penelitian ini antara lain, untuk mengembangkan Media Konversi Pecahan dan menerapkannya pada pembelajaran Matematika dengan materi pecahan pada siswa kelas $\mathrm{V}$ Sekolah Dasar; mendeskripsikan penggunaan Media Konversi Pecahan pada materi pecahan pada siswa kelas V Sekolah Dasar; serta mendeskripsikan peningkatan hasil belajar siswa kelas $\mathrm{V}$ melalui penggunaan Media Konversi Pecahan.

Melalui penelitian ini, diharapkan diperoleh manfaat, baik bagi guru, siswa, dan sekolah. Bagi guru, Media Konversi Pecahan diharapkan dapat meningkatkan kreativitas guru dalam menciptakan media pembelajaran Matematika sesuai dengan kompetensi yang dibutuhkan di abad 21; serta memberikan pengalaman untuk menciptakan media pembelajaraan yang efektif. Manfaat media ini bagi siswa yaitu meningkatkan motivasi dan semangat siswa dalam mempelajari materi pecahan; meningkatkan keterampilan siswa khususnya keterampilan berpikir tingkat tinggi; meningkatkan aktivitas dan kreativitas siswa; serta meningkatkan hasil belajar siswa. Manfaat bagi sekolah yaitu 
meningkatkan kualitas pembelajaran Matematika dalam rangka mewujudkan penguatan pendidikan karakter; menambah inventaris media pembelajaran Matematika; serta memotivasi rekan guru yang lain untuk menciptakan inovasi pembelajaran.

\section{B. Metode}

Media ini dibuat dengan jenis visual interaktif. Siswa dapat belajar langsung menggunakan media. Media Konversi Pecahan dapat disentuh secara langsung oleh siswa. Media Konversi Pecahan menjelaskan tentang konsep pecahan, konsep penjumlahan pecahan, konsep pengurangan pecahan, konsep perkalian pecahan, konsep pembagian pecahan, konsep besar kecilnya pecahan, dan konsep persamaan pecahan. Artinya dalam satu media ini semua konsep pecahan data dapat dijelaskan.

Media ini dibuat dengan sederhana dan dirancang untuk dapat diaplikasikan dengan mudah. Siswa akan aktif dan berinteraksi langsung dengan media karena dia yang memasang dan membongkar sendiri balok-balok pecahan ketika menyelesaikan suatu soal. Melalui proses memasang dan membongkar balok pecahan, diharapkan siswa akan menginternalisasi semua konsep pecahan.

Media ini dibuat dalam bentuk seperti bagan yang dibuat dengan bahan baku utama berupa kayu triplek. Kayu triplek dipilih karena bahannya mudah diperoleh di seluruh wilayah Indonesia, sehingga nantinya media ini dapat dibuat oleh guru lain. Kayu triplek juga murah, mudah dibentuk karena tipis, lunak, dan awet. Selanjutnya bagan yang mendasari kayu triplek ini dibuat dengan kertas asturo berbagai macam warna. Tujuan penggunaan berbagai macam warna yaitu agar media ini menarik perhatian siswa serta untuk membedakan masing-masing jenis pecahan.

Setelah menggunakan media ini, siswa juga diarahkan untuk menghasilkan produk yaitu berupa diagram konversi pecahan. Diagram ini dibuat pada kertas gambar dengan tujuan untuk melatih pengetahuan, dan ketrampilan berpikir tingkat tinggi (HOTS) yang dimiliki siswa. 
Pembuatan diagram yang benar sesuai intruksi soal yang diberikan, dapat digunakan guru untuk mengonfirmasi tingkat pemahaman siswa.

Pembuatan Media Konversi Pecahan sangat mudah, murah, dan tidak memerlukan waktu yang lama. Bahan-bahan pembuatan media ini mudah diperoleh di berbagai wilayah di Indonesia. Bahan-bahan tersebut dapat diperoleh di toko bangunan dan toko alat tulis. Untuk wilayah terpencil di Indonesia, pembelian alat dan bahan dapat dilakukan secara online, misalnya untuk pembelian salah satu bahan yaitu magnet.

Pembuatan media ini dilakukan dengan berbagai tahapan. Tahap yang pertama yaitu menggambar bentuk media. Rancangan media digambar melalui komputer dengan aplikasi Microsoft Word. Rancangan gambar ini sangat membantu dalam penentuan skala media, pemilihan huruf yang dipakai, dan juga pemilihan desain warna. Setelah gambar dibuat, tahap yang kedua yaitu membeli bahan-bahan sesuai dengan rancangan gambar di toko bangunan dan di toko alat tulis. Tahap ketiga yaitu pembuatan media. Bahan-bahan yang telah siap, dibentuk dan disusun sesuai dengan rancangan gambar yang telah dibuat.

Alat dan bahan yang dibutuhkan dalam pembuatan media konversi pecahan ini yaitu:

\begin{tabular}{|l|l|l|}
\hline No & \multicolumn{1}{|c|}{ Alat } & \multicolumn{1}{c|}{ Bahan } \\
\hline 1. & Penggaris & Triplek \\
2. & Gunting & Magnet \\
3. & Gergaji & Kertas Asturo \\
4. & Cutter & Kertas Karton \\
5. & Spidol & Double Tape \\
6. & Pensil & Lem Kertas \\
7. & Ballpoint & Lem Kayu \\
8. & Penghapus & Seng \\
\hline
\end{tabular}

Tabel 3.1 Alat dan Bahan Pembuatan Media Pembelajaran

Cara pembuatan Media Konversi Pecahan, yaitu:

1. Potong triplek sesuai ukuran yang diinginkan

2. Bagi triplek menjadi tiga bagian dan beri garis dengan spidol 
3. Tempelkan kertas asturo untuk menutup triplek

4. Buat balok-balok pecahan menggunakan kertas karton

5. Tutup balok-balok pecahan menggunakan kertas asturo

6. Pasang magnet pada kertas karton dan triplek dengan lem kayu

\section{Proses Penemuan/Pembaharuan}

Media Konversi Pecahan digunakan untuk menjelaskan konsep pecahan. Media Konversi Pecahan dapat mengkongkretkan materi pecahan. Media ini sangat sederhana dan mudah diaplikasikan. Cara menggunakan Media Konversi Pecahan dan contoh soalnya yaitu

a. Operasi Persamaan Pecahan

1) Bentuk persen dari $3 / 5$ adalah ...

Langkah kerjanya yaitu

a) Ambil balok sebanyak tiga buah lalu tempelkan ke bagan pecahan

b) Ambil balok sebanyak tiga buah lalu tempelkan ke bagan persen

c) Lihat bilangan di sebelah persen

d) Hasilnya adalah $60 \%$

2) Bentuk desimal dari $120 \%$ adalah ...

Langkah kerjanya yaitu

a) Ambil balok sebanyak enam buah lalu tempelkan ke bagan persen

b) Ambil balok sebanyak enam buah lalu tempelkan ke bagan desimal

c) Lihat bilangan di sebelah desimal

d) Hasilnya adalah 1,2

b. Operasi Penjumlahan Pecahan

1) Hasil dari $2 / 5+1 / 5$ adalah $\ldots$

a) Ambil balok sebanyak dua buah lalu tempelkan ke bagan pecahan 
b) Ambil balok sebanyak satu buah lalu tempelkan di atas bagan pecahan sebelumnya

c) Lihat bilangan di sebelah balok pecahan biasa

d) Hasilnya adalah $3 / 5$

2) Hasil dari $0,8+0,6$ adalah ...

a) Ambil balok sebanyak empat buah lalu tempelkan ke bagan desimal

b) Ambil balok sebanyak tiga buah lalu tempelkan ke bagan desimal

c) Lihat bilangan di sebelah balok desimal

d) Hasilnya adalah 1,4

c. Operasi Pengurangan Pecahan

1) Hasil dari $160 \%-120 \% \ldots$

a) Ambil balok sebanyak delapan buah lalu tempelkan ke bagan persen

b) Ambil balok sebanyak enam buah dari delapan balok yang telah ditempelkan sebelumnya

c) Lihat bilangan di sebelah balok persen

d) Hasilnya adalah $40 \%$

2) Hasil dari 1,8 - 0,6 adalah ...

a) Ambil balok sebanyak sembilan buah lalu tempelkan ke bagan desimal

b) Ambil balok sebanyak tiga buah dari balok yang telah ditempelkan sebelumnya

c) Lihat bilangan di sebelah balok desimal

d) Hasilnya adalah 1,2

d. Operasi Perkalian Pecahan

1) Hasil dari $3 \times 2 / 5$ adalah ...

a) Ambil balok sebanyak dua buah lalu tempelkan ke bagan pecahan

b) Ambil balok sebanyak dua buah lalu tempelkan ke bagan pecahan 
c) Ambil balok sebanyak dua buah lalu tempelkan ke bagan pecahan

d) Lihat bilangan di sebelah pecahan

e) Hasilnya adalah $11 / 5$

2) Hasil dari $4 \times 0,4$ adalah...

a) Ambil balok sebanyak dua buah lalu tempelkan ke bagan desimal

b) Ambil balok sebanyak dua buah lalu tempelkan ke bagan desimal

c) Ambil balok sebanyak dua buah lalu tempelkan ke bagan desimal

d) Ambil balok sebanyak dua buah lalu tempelkan ke bagan desimal

e) Lihat bilangan di sebelah desimal

f) Hasilnya adalah 1,6

e. Operasi Pembagian Pecahan

1) Hasil $1,2: 3$ adalah ...

a) Ambil balok sebanyak enam buah lalu tempelkan ke bagan desimal

b) Ambil satu balok tempatkan terpisah

c) Lakukan sampai tinggi balok sama

d) Lihat bilangan disebelah desimal

e) Hasilnya adalah 0,4

2) Hasil $160 \%: 8$ adalah $\ldots$

a) Ambil balok sebanyak delapan buah lalu tempelkan ke bagan persen

b) Ambil satu balok tempatkan terpisah

c) Lakukan sampai tinggi balok sama

d) Lihat bilangan di sebelah persen

e) Hasilnya adalah $20 \%$

Penggunaan Konversi Pecahan sangat mudah. Langkah kerjanya dibuat sangat sederhana sehingga mudah dimengerti oleh siswa. Untuk 
mengetahui bentuk pecahan yang berbeda hanya dengan melihat bagan pecahan lain di sebelah kiri atau kanan.

\section{HASIL DAN PEMBAHASAN}

\section{Aplikasi Praktis dalam Pembelajaran}

Media Konversi Pecahan telah diterapkan pada siswa kelas V SD Ngentak dalam 4 kegiatan pembelajaran. Kegiatan pembelajaran yang dilakukan telah dibagi menjadi 2 siklus. Setiap siklus kegiatan dilaksanakan 2 kali pertemuan. Siklus 1 dilaksanakan pada tanggal 17 dan 18 April 2019 sedangkan siklus 2 dilaksanakan pada tanggal 22 dan 24 April 2019. Rinciannya adalah:

\begin{tabular}{|c|l|c|c|c|}
\hline No & Hari/Tanggal & Jam Pelajaran & Siklus & Pertemuan \\
\hline 1. & Rabu, 17 April 2019 & $1-2(07.15-08.25)$ & I & 1 \\
\hline 2. & Kamis, 18 April 2019 & $1-2(07.15-08.25)$ & I & 2 \\
\hline 3. & Senin, 22 April 2019 & $1-2(07.50-09.00)$ & II & 3 \\
\hline 4. & Rabu, 24 April 2019 & $1-2(07.15-08.25)$ & II & 4 \\
\hline
\end{tabular}

\section{Tabel 3.2 Jadwal pelaksanaan tindakan}

Adapun deskripsi tindakan siklus 1 dan 2 yaitu :

1. Pertemuan Pertama

Tahapan-tahapan kegiatan pembelajaran siklus 1 pertemuan pertama adalah:

a. Siswa dikondisikan untuk siap mengikuti kegiatan pembelajaran.

b. Guru mengucapkan salam pembuka.

c. Siswa berdoa sesuai agama dan keyakinannya masing-masing.

d. Guru membacakan daftar absensi kehadiran.

e. Guru melakukan apersepsi tentang materi yang telah dikuasai sebelumnya.

f. Guru memberikan motivasi pada siswa.

g. Siswa mengamati penjelasan guru tentang Media Konversi Pecahan dan cara penggunaannya. (mengamati) 
h. Siswa mencoba menggunakan Media Konversi Pecahan untuk mengerjakan contoh soal. (mencoba)

i. Guru menjelaskan tugas yang akan diberikan.

j. Siswa membuat diagram pecahan sesuai dengan soal. (mencoba)

k. Guru melakukan tanya jawab dengan siswa untuk mengonfirmasi pekerjaan mereka. (menanya)

1. Siswa menyimpulkan hasil pekerjaan mereka. (mengomunikasikan)

$\mathrm{m}$. Guru memberikan motivasi atas pekerjaan yang telah dilakukan siswa.

n. Guru melakukan refleksi pembelajaran yang telah dilakukan.

o. Guru menutup pelajaran.

2. Pertemuan Kedua

Tahapan -tahapan kegiatan dalam pertemuan kedua antara lain:

a. Siswa dikondisikan untuk siap mengikuti kegiatan pembelajaran.

b. Guru mengucapkan salam pembuka.

c. Siswa berdoa sesuai agama dan keyakinannya masing-masing.

d. Guru membacakan daftar absensi kehadiran.

e. Guru melakukan apersepsi tentang materi yang telah dikuasai sebelumnya.

f. Guru menjelaskan tujuan pembelajaran.

g. Guru memberikan motivasi pada siswa.

h. Siswa mengulangi pembelajaran yang telah dilakukan.

i. Guru memberikan latihan soal kepada siswa.

j. Siswa mengerjakan latihan soal yang diberikan oleh guru.

k. Siswa dan guru melakukan tanya jawab atas masing-masing soal.

1. Siswa berdiskusi tentang diagram yang telah mereka buat.

m. Siswa mempresentasikan diagramnya.

n. Guru mengkonfirmasi digram siswa.

Pelaksanaan siklus 1 telah berjalan lancar sesuai dengan perencanaan. Namun dari pelaksanaan siklus 1 tersebut ditemukan beberapa kelemahan antara lain : (1) Siswa masih kesulitan dalam 
memahami materi pembagian pecahan, (2) Siswa masih terlihat malumalu sehingga masih ragu untuk mencoba menggunakan media pembelajaran, (3) Guru kehabisan waktu karena terlalu sibuk saat menjelaskan media pembelajaran, (4) Kriteria Ketuntasan Minimal belum terpenuhi.

Selain kelemahan, beberapa kelebihan yang telah dicapai dalam kegiatan pembelajaran siklus I antara lain: (1) Siswa cukup tertarik dengan media pembelajaran yang telah digunakan saat pembelajaran, (2) Pelaksanaan kegiatan pembelajaran yang dilakukan secara umum sudah cukup sesuai dengan Rencana Pelaksanaan Pembelajaran (RPP) yang telah dibuat, (3) Pembelajaran berlangsung dengan tenang dan kondusif.

Salah satu kelemahan yang ditunjukkan pada pembelajaran siklus I yaitu belum terpenuhinya KKM, oleh karena itu perlu untuk dilakukan perbaikan melalui pelaksanaan pembelajaran siklus 2. Pembelajaran siklus 2 dilaksanakan dengan melakukan pembelajaran 3 dan 4. Adapun rincian kegiatan pembelajarannya yaitu:

\section{Pertemuan Ketiga}

Tahapan -tahapan kegiatan dalam pertemuan ketiga antara lain:

a. Siswa dikondisikan untuk siap mengikuti kegiatan pembelajaran

b. Guru mengucapkan salam pembuka

c. Siswa berdoa sesuai agama dan keyakinannya masing-masing

d. Guru membacakan daftar absensi kehadiran

e. Guru melakukan apersepsi tentang materi

f. Guru menjelaskan tujuan pembelajaran

g. Guru memberikan motivasi pada siswa

h. Siswa mengamati penjelasan guru tentang Media Konversi Pecahan dan cara penggunaannya (mengamati).

i. Siswa mencoba menggunakan Media Konversi Pecahan untuk mengerjakan contoh soal (mencoba). 
j. Guru menjelaskan tugas yang akan diberikan.

k. Siswa membuat diagram pecahan sesuai dengan soal (mencoba).

1. Guru melakukan tanya jawab dengan siswa untuk mengonfirmasi pekerjaan mereka (menanya).

m. Siswa menyimpulkan hasil pekerjaan mereka (mengomunikasikan).

n. Guru memberikan motivasi atas pekerjaan yang telah dilakukan siswa.

o. Guru melakukan refleksi pembelajaran yang telah dilakukan untuk menanyakan keselitan yang dialami oleh siswa.

p. Guru menutup pelajaran.

2. Pertemuan Keempat

Tahapan -tahapan kegiatan dalam pertemuan keempat antara lain:

a. Siswa dikondisikan untuk siap mengikuti kegiatan pembelajaran

b. Guru mengucapkan salam pembuka

c. Siswa berdoa sesuai agama dan keyakinannya masing-masing

d. Guru membacakan daftar absensi kehadiran

e. Guru melakukan apersepsi tentang materi yang telah dikuasai sebelumnya

f. Guru menjelaskan tujuan pembelajaran

g. Guru memberikan motivasi pada siswa

h. Siswa mengulangi pembelajaran yang telah dilakukan.

i. Guru memberikan latihan soal kepada siswa.

j. Siswa mengerjakan latihan soal yang diberikan oleh guru.

k. Siswa dan guru melakukan tanya jawab atas masing-masing soal.

1. Siswa berdiskusi tentang diagram yang telah mereka buat.

m. Siswa mempresentasikan diagramnya.

n. Guru mengkonfirmasi diagram siswa.

Saat pembelajaran siklus 2, semua siswa ingin menggunakan Media Konversi Pecahan. Akibatnya mereka harus mengantri untuk dapat menggunakannya. Pada pembelajaran siklus 2 ini antusiasme siswa 
terlihat lebih meningkat dari pada pembelajaran siklus 1. Kelemahan saat pembelajaran siklus 1 sudah tidak terlihat lagi. Sebaliknya banyak sekali kelebihan yang ditunjukkan dalam pembelajaran siklus 2 antara lain: (1) Siswa sangat tertarik untuk mencoba media pembelajaran, (2) Pelaksanaan pembelajaran telah sesuai dengan Rencana Pelaksanaan Pembelajaran (RPP), (3) Telah terpenuhinya Kriteria Ketuntasan Minimal.

\section{Data Hasil Aplikasi Praktis Inovasi Pembelajaran}

Penerapan Media Konversi Pecahan telah dilaksanakan sesuai dengan RPP yang telah disusun. Data hasil aplikasi inovasi pembelajaran terdiri dari data hasil evaluasi, data aktivitas siswa, dan data hasil produk siswa.

a. Data Hasil Evaluasi

\begin{tabular}{|c|c|c|c|c|c|}
\hline \multirow{2}{*}{ No } & \multirow{2}{*}{ Nama Siswa } & \multicolumn{2}{|c|}{ PAS } & \multirow{2}{*}{ Siklus I } & \multirow{2}{*}{ Siklus 2} \\
\hline & & KD 1 & KD 2 & & \\
\hline 1. & Aad Syah Rifai & 60 & 25 & 95 & 100 \\
\hline 2. & Annisha Erinne Defi & 67 & 31 & 40 & 75 \\
\hline 3. & Diaz Ircham Maulana & 53 & 31 & 60 & 85 \\
\hline 4. & Elsa Pradita Desty & 60 & 44 & 90 & 100 \\
\hline 5. & Fiorentina Annisa Nur H & 40 & 50 & 60 & 85 \\
\hline 6. & Hafid Hidayat & 40 & 63 & 70 & 95 \\
\hline 7. & Hana Nur Azizah & 47 & 44 & 90 & 80 \\
\hline 8. & Hayu Putri Aninditya & 80 & 63 & 100 & 100 \\
\hline 9. & Jezzy Eka Anggraeni & 87 & 56 & 95 & 100 \\
\hline 10. & Khoirunisa Eka W & 73 & 69 & 80 & 95 \\
\hline 11. & Kirenata Lasiyamiani & 55 & 81 & 90 & 80 \\
\hline 12. & Muhammad Zusax Amrulloh & 53 & 50 & 95 & 90 \\
\hline 13. & Nabila Choirunnisa & 40 & 44 & 45 & 85 \\
\hline 14. & Primadani Faradilla S.P & 47 & 31 & 15 & 50 \\
\hline 15. & Zaki Saputra & 47 & 38 & 90 & 95 \\
\hline 16. & Zulaikha Azizah K.S.K & 27 & 25 & 20 & 80 \\
\hline & Jumlah & 876 & 745 & 1135 & 1395 \\
\hline & Rata-rata & 55 & 47 & 71 & 87 \\
\hline
\end{tabular}

\section{Tabel 3.3 Daftar Nilai Hasil Belajar Siswa}

b. Data Aktivitas Siswa

\begin{tabular}{|c|c|c|c|c|c|c|c|c|c|c|c|}
\hline \multirow{3}{*}{ No } & \multirow{3}{*}{ Nama } & \multicolumn{5}{|c|}{ Siklus 1} & \multicolumn{5}{|c|}{ Siklus 2} \\
\hline & & \multicolumn{3}{|c|}{ Aspek Penilaian } & \multirow{2}{*}{ Jml } & \multirow{2}{*}{ Nilai } & \multicolumn{3}{|c|}{ Aspek Penilaian } & \multirow{2}{*}{ Jml } & \multirow{2}{*}{ Nilai } \\
\hline & & $\mathbf{A}$ & B & $\mathrm{C}$ & & & $\mathbf{A}$ & B & $\mathrm{C}$ & & \\
\hline 1. & Aad Syah Rifai & 3 & 4 & 3 & 10 & $\mathrm{~B}$ & 4 & 4 & 3 & 11 & A \\
\hline 2. & Annisha Erinne Defi & 3 & 3 & 3 & 9 & B & 3 & 4 & 4 & 11 & $\mathrm{~A}$ \\
\hline 3. & Diaz Ircham Maulana & 3 & 3 & 3 & 9 & B & 4 & 4 & 3 & 11 & A \\
\hline 4. & Elsa Pradita Desty & 4 & 3 & 3 & 10 & $\mathrm{~B}$ & 4 & 4 & 4 & 12 & A \\
\hline 5. & Fiorentina Annisa & 3 & 2 & 2 & 7 & $\mathrm{C}$ & 3 & 3 & 3 & 9 & B \\
\hline
\end{tabular}


Penerapan Media Konversi Pecahan Untuk Meningkatkan Hasil Pembelajaran Matematika

Roni Rahmawanto

\begin{tabular}{|c|c|c|c|c|c|c|c|c|c|c|c|}
\hline \multirow{3}{*}{ No } & \multirow{3}{*}{ Nama } & \multicolumn{5}{|c|}{ Siklus 1} & \multicolumn{5}{|c|}{ Siklus 2} \\
\hline & & \multicolumn{3}{|c|}{ Aspek Penilaian } & \multirow{2}{*}{$\mathrm{Jml}$} & \multirow{2}{*}{ Nilai } & \multicolumn{3}{|c|}{ Aspek Penilaian } & \multirow{2}{*}{$\mathrm{Jml}$} & \multirow{2}{*}{ Nilai } \\
\hline & & $\mathbf{A}$ & B & $\mathrm{C}$ & & & $\mathbf{A}$ & B & $\mathrm{C}$ & & \\
\hline 6. & Hafid Hidayat & 3 & 3 & 3 & 9 & B & 4 & 3 & 4 & 11 & A \\
\hline 7. & Hana Nur Azizah & 2 & 3 & 2 & 7 & $\mathrm{C}$ & 3 & 3 & 3 & 9 & $\mathrm{~B}$ \\
\hline 8. & Hayu Putri Aninditya & 4 & 3 & 3 & 10 & $\mathrm{~B}$ & 4 & 4 & 4 & 12 & $\mathrm{~A}$ \\
\hline 9. & Jezzy Eka Anggraeni & 3 & 3 & 3 & 9 & B & 4 & 4 & 4 & 12 & A \\
\hline 10. & Khoirunisa Eka W & 3 & 3 & 3 & 9 & B & 4 & 4 & 4 & 12 & A \\
\hline 11. & Kirenata Lasiyamiani & 2 & 3 & 3 & 8 & $\mathrm{C}$ & 3 & 4 & 4 & 11 & $\overline{\mathrm{A}}$ \\
\hline 12. & Muhammad Zusax A & 2 & 2 & 3 & 7 & $\mathrm{C}$ & 3 & 3 & 3 & 9 & $\mathrm{~B}$ \\
\hline 13. & Nabila Choirunnisa & 3 & 3 & 3 & 9 & $\mathrm{~B}$ & 3 & 3 & 4 & 10 & $\mathrm{~B}$ \\
\hline 14. & Primadani Faradilla & 2 & 2 & 2 & 6 & C & 3 & 3 & 3 & 9 & B \\
\hline 15. & Zaki Saputra & 3 & 3 & 3 & 9 & $\mathrm{~B}$ & 4 & 4 & 3 & 11 & $\mathrm{~A}$ \\
\hline 16. & Zulaikha Azizah K.S & 3 & 2 & 3 & 8 & $\mathrm{C}$ & 3 & 3 & 3 & 9 & $\mathrm{~B}$ \\
\hline & Jumlah & 46 & 45 & 45 & 136 & & 56 & 57 & 56 & 169 & \\
\hline & Rata-rata & 2.9 & 2.8 & 2.8 & 8.5 & $\mathrm{C}$ & 3.5 & 3.6 & 3.5 & 10.6 & B \\
\hline
\end{tabular}

Tabel 3.4 Data Hasil Aktivitas Siswa

Keterangan:

$\mathrm{A}=$ Mendengarkan

$\mathrm{B}=$ Tanya Jawab

$\mathrm{C}=$ Simulasi
Skor :

4 = sangat baik

$3=$ baik

$2=$ cukup

$1=$ kurang
Konversi Nilai :
$\mathrm{A}=11-12$
$\mathrm{B}=9-10$
$\mathrm{C}=6-8$
$\mathrm{D}=<5$

c. Data Hasil Produk Siswa

\begin{tabular}{|c|c|c|c|c|c|c|c|c|c|c|c|}
\hline \multirow{3}{*}{ No } & \multirow{3}{*}{ Nama } & \multicolumn{5}{|c|}{$\begin{array}{rr}\text { Siklus } 1 \\
\end{array}$} & \multicolumn{5}{|c|}{$\begin{array}{ll}\text { Siklus 2 } \\
\end{array}$} \\
\hline & & \multicolumn{3}{|c|}{ Aspek Penilaian } & \multirow{2}{*}{$\mathrm{Jml}$} & \multirow{2}{*}{ Nilai } & \multicolumn{3}{|c|}{ Aspek Penilaian } & \multirow{2}{*}{ Jml } & \multirow{2}{*}{ Nila } \\
\hline & & A & B & $\mathrm{C}$ & & & A & B & C & & \\
\hline 1. & Aad Syah Rifai & 4 & 3 & 3 & 10 & B & 4 & 4 & 3 & 11 & $\mathrm{~A}$ \\
\hline 2. & Annisha Erinne Defi & 4 & 3 & 3 & 10 & B & 4 & 4 & 3 & 11 & A \\
\hline 3. & Diaz Ircham Maulana & 3 & 2 & 2 & 7 & $\mathrm{C}$ & 3 & 3 & 3 & 9 & $\mathrm{~B}$ \\
\hline 4. & Elsa Pradita Desty & 4 & 3 & 3 & 10 & $\mathrm{~B}$ & 4 & 3 & 4 & 11 & A \\
\hline 5. & Fiorentina Annisa & 2 & 2 & 3 & 7 & C & 3 & 3 & 3 & 9 & B \\
\hline 6. & Hafid Hidayat & 3 & 2 & 2 & 7 & $\mathrm{C}$ & 4 & 3 & 3 & 10 & $\mathrm{~B}$ \\
\hline 7. & Hana Nur Azizah & 2 & 3 & 3 & 8 & $\mathrm{C}$ & 3 & 3 & 3 & 9 & $\mathrm{~B}$ \\
\hline 8. & Hayu Putri Aninditya & 4 & 3 & 3 & 10 & $\mathrm{~B}$ & 4 & 3 & 4 & 11 & $\mathrm{~A}$ \\
\hline 9. & Jezzy Eka Anggraeni & 4 & 4 & 3 & 11 & $\mathrm{~A}$ & 4 & 3 & 4 & 11 & $\mathrm{~A}$ \\
\hline 10. & Khoirunisa Eka W & 4 & 3 & 3 & 10 & $\mathrm{~B}$ & 4 & 4 & 3 & 11 & $\mathrm{~A}$ \\
\hline 11. & Kirenata Lasiyamiani & 4 & 4 & 3 & 11 & $\mathrm{~A}$ & 4 & 4 & 3 & 11 & $\mathrm{~A}$ \\
\hline 12. & Muhammad Zusax A & 2 & 2 & 2 & 6 & $\mathrm{C}$ & 3 & 2 & 3 & 8 & $\mathrm{C}$ \\
\hline 13. & Nabila Choirunnisa & 3 & 2 & 2 & 7 & $\mathrm{C}$ & 3 & 3 & 4 & 10 & $\mathrm{~B}$ \\
\hline 14. & Primadani Faradilla & 2 & 2 & 3 & 7 & $\mathrm{C}$ & 3 & 2 & 3 & 8 & $\mathrm{C}$ \\
\hline 15. & Zaki Saputra & 3 & 2 & 3 & 8 & $\mathrm{C}$ & 4 & 4 & 3 & 11 & $\mathrm{~A}$ \\
\hline 16. & Zulaikha Azizah K.S & 3 & 3 & 2 & 8 & $\mathrm{C}$ & 3 & 3 & 3 & 9 & B \\
\hline & Jumlah & 51 & 43 & 43 & 137 & & 57 & 51 & 52 & 160 & \\
\hline & Rata-rata & 3.2 & 2.7 & 2.7 & 8.6 & $\mathrm{C}$ & 3.6 & 3.2 & 3.3 & 10.0 & B \\
\hline
\end{tabular}

Tabel 3.5 Data Hasil Produk Diagram

Keterangan:

A $=$ Penguasaan Konsep

$\mathrm{B}=$ Kerapian

$\mathrm{C}=$ Komposisi
Skor :

4 = sangat baik

$3=$ baik

2 = cukup

$1=$ kurang
Konversi Nilai :

$\mathrm{A}=11-12$

$\mathrm{B}=9-10$

$\mathrm{C}=6-8$

$\mathrm{D}=<5$ 


\section{Analisis Hasil Aplikasi Praktis Inovasi Pembelajaran}

Berdasarkan data hasil aplikasi praktis, dapat dianalisis berdasarkan data hasil evaluasi, data aktivitas siswa, dan data hasil produk diagram.

\section{a. Data Hasil Evaluasi}

Pembelajaran siklus 1 telah dilaksanakan sesuai rencana yang telah dibuat. Hasil pembelajaran siklus 1 menunjukkan belum terpenuhinya target KKM yang telah ditetapkan sebesar $75 \%$ dari keseluruhan siswa. Beberapa permasalahan yang menyebabkan hal tersebut antara lain:

1) Tidak semua siswa mempunyai kesempatan mencoba media pembelajaran karena terbatasnya waktu.

2) Guru kurang dalam memberikan contoh soal yang variatif dan mudah dimengerti siswa.

3) Guru terlihat tergesa-gesa saat menjelaskan materi.

Analisis hasil belajar siklus I sebagai berikut:

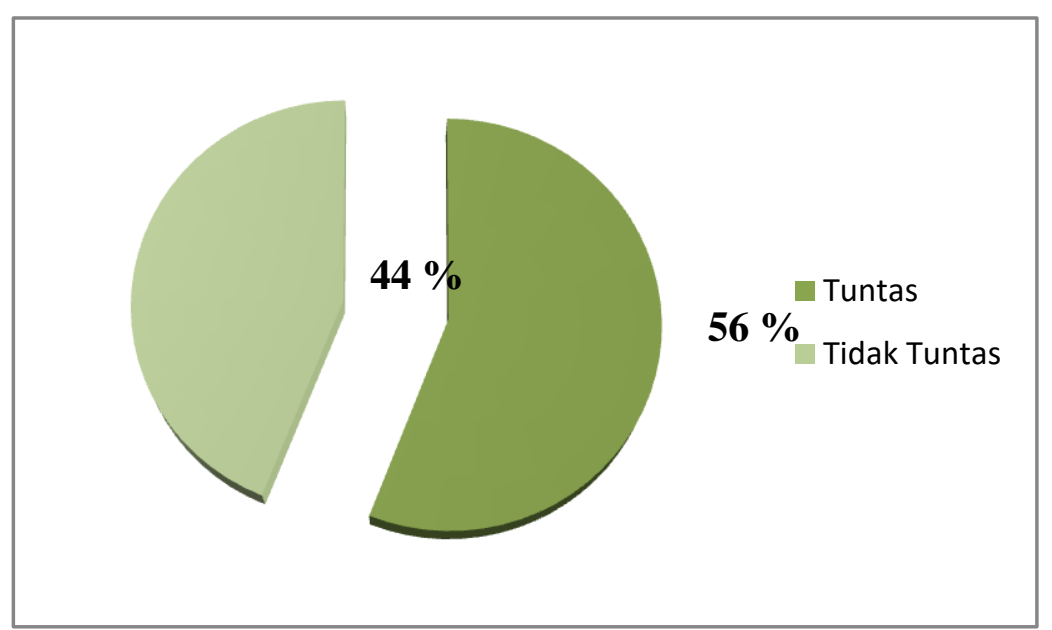

Gambar 3.2 Diagram Nilai Hasil Belajar Siklus 1 
Perbaikan pembelajaran siklus 1 yang direncanakan untuk memperbaiki hasil belajar yaitu (1) guru menjelaskan kembali materi dan cara menggunakan Media Konversi Pecahan secara lebih mudah dimengerti siswa, (2) Guru lebih memperhatikan waktu dalam menyusun rencana pelaksanaan pembelajaran, dan (3) Guru memancing rasa ingin tahu siswa.

Setelah pelaksanaan pembelajaran siklus 2, didapatkan hasil yang berbeda dari siklus 1 . Hasil pembelajaran siklus 2 ini menunjukkan kenaikan. Hasil pembelajaran siklus 2 telah menunjukkan kesesuaian dengan kriteria keberhasilan pembelajaran yaitu $75 \%$ siswa mendapatkan nilai minimal 75 . Peningkatan hasil pembelajaran di siklus 2 disebabkan oleh hal-hal antara lain :

1) Siswa telah mulai terbiasa menggunakan Media Konversi Pecahan.

2) Siswa lebih antusias dalam mempelajari materi menggunakan Media Konversi Pecahan terbukti saat jam istirahat, mereka tidak mau istirahat dan menggunakan waktu istirahat untuk mempelajari media pembelajaran.

3) Siswa memiliki lebih banyak waktu untuk bertanya jawab dengan guru.

4) Guru membimbing siswa saat membuat diagram pecahan.

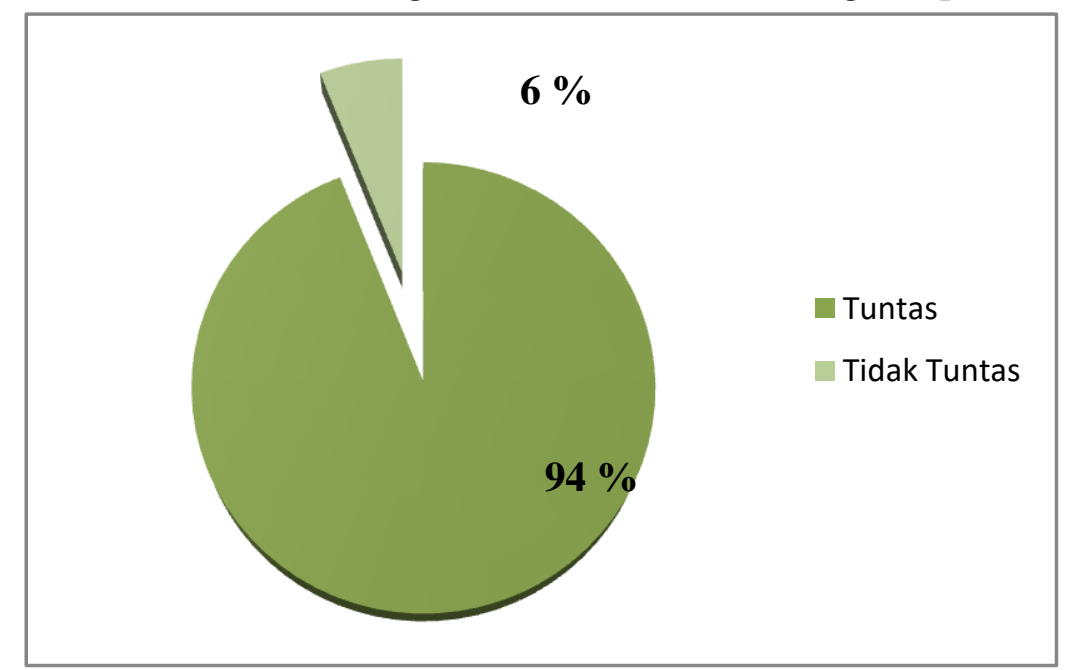

Gambar 3.3 Diagram Nilai Hasil Belajar Siklus 2 
Kelemahan yang ditemukan saat pembelajaran siklus 2 yaitu masih ada siswa yang mendapat nilai di bawah KKM. Kelemahan tersebut dijadikan pelajaran bagi guru untuk lebih tekun saat membimbing siswa dan memancing siswa untuk berani menyampaikan pendapat saat dia belum memahami materi pelajaran. Kelemahan tersebut tidak mempengaruhi keberhasilan penelitian, karena penelitian sudah sesuai dengan kriteria kesuksesan yang telah ditetapkan sebelumnya.

\section{b. Data Aktivitas Siswa}

Data aktivitas pembelajaran siklus 1 pada kategori cukup dengan nilai rata-rata 8,5. Hal ini belum sesuai dengan kriteria yang ditetapkan yaitu pada kategori baik yaitu 9,0 - 10,9. Nilai rata-rata aktivitas pada kategori cukup disebabkan karena:

1) Siswa terlihat kurang dalam memperhatikan penjelasan guru.

2) Siswa terlihat malu dan ragu dalam mencoba menggunakan Media Konversi Pecahan.

3) Siswa terlihat kurang aktif saat kegiatan pembelajaran hal ini dilihat dari minimnya tanya jawab antara guru dengan siswa.

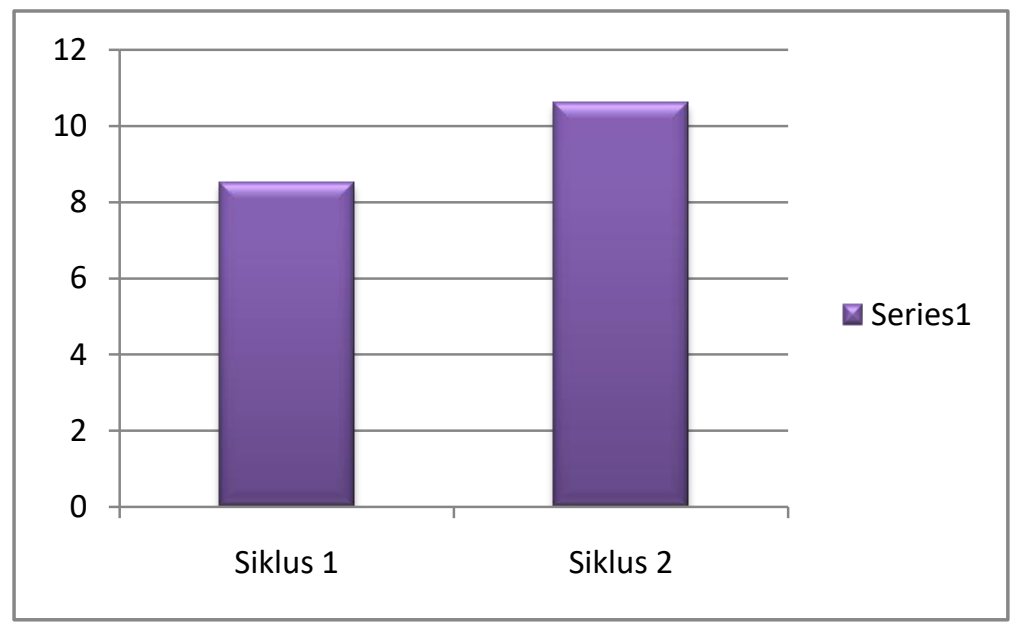

Gambar 3.4 Diagram Aktivitas Siswa

Usaha meningkatkan aktivitas pembelajaran pada siklus 2 antara lain: (1) Guru mengkondisikan siswa bahwa materi pecahan sangat 
penting untuk dikuasai sehingga siswa harus memperhatikan penjelasan guru, (2) Guru memancing siswa untuk aktif bertanya jawab, dan (3) Guru memberi apresiasi bagi siswa yang terlibat aktif dalam kegiatan pembelajaran.

Perbaikan aktivitas pada siklus 2 menunjukkan keberhasilan. Hasil aktivitas pembelajaran siklus 2 berada pada kriteria baik dengan nilai rata-rata 10,6. Peningkatan ini disebabkan:

1) Siswa lebih mendengarkan penjelasan guru saat simulasi penggunaan media.

2) Siswa tidak malu lagi dalam kegiatan tanya jawab dengan guru.

3) Siswa lebih aktif terlibat dalam simulasi penggunaan media.

\section{c. Data Hasil Produk Siswa}

Hasil produk siswa berupa diagram pecahan pada siklus 1 menunjukkan nilai rata-rata 8,6 dan berada pada kategori cukup yaitu dikisaran 6,0 - 8,9. Hal ini disebabkan oleh:

1) Sebagian siswa masih belum memahami tentang konsep pecahan yang dipelajarinya.

2) Guru terlihat kurang dalam membimbing siswa membuat diagram.

3) Siswa tergesa-gesa dalam membuat diagram sehingga hasilnya kurang rapi.

4) Sebagian siswa tidak membawa pewarna. 


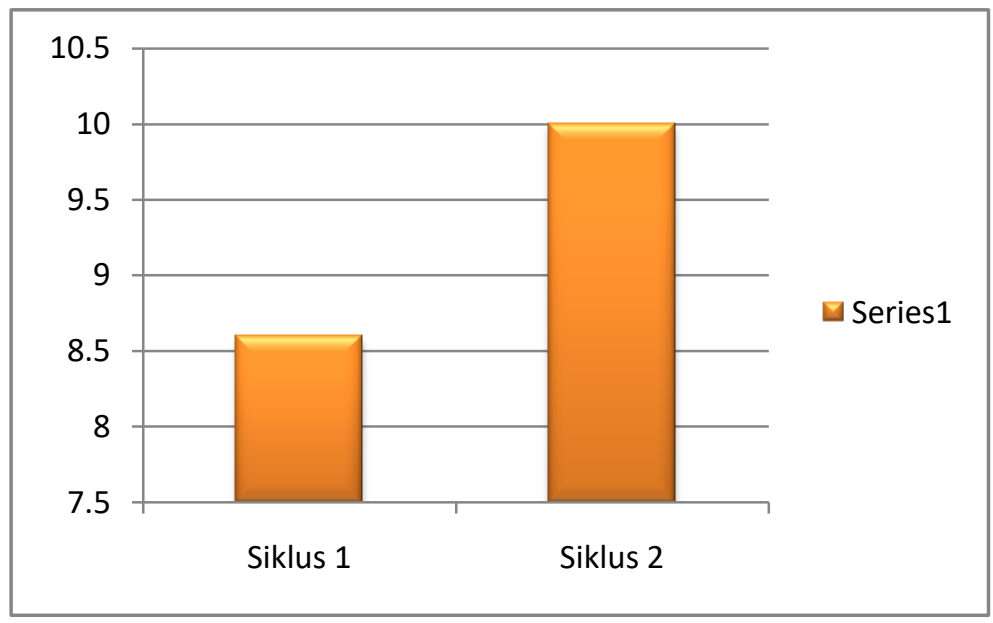

Gambar 3.5 Diagram Produk Siswa

Perbaikan terhadap produk yang dihasilkan siswa pada siklus 1 yaitu dengan (1) Guru membimbing siswa dalam membuat diagram siswa dan memastikan mereka sudah memahami konsep pecahan, (2) Guru memperingatkan siswa untuk tidak tergesa-gesa dalam membuat diagram, (3) Guru menugaskan siswa untuk membawa pewarnanya sendiri-sendiri.

Pada pelaksanaan siklus 2 terjadi peningkatan terhadap hasil produk siswa. Hasil nilai rata-rata berdasarkan kriteria yang ditetapkan berada di angka 10,0. Hasil ini telah sesuai dengan mempunyai kategori baik. Peningkatan hasil ini dikarenakan :

1) Siswa sudah memahami konsep pecahan yang dipelajarinya.

2) Siswa tidak tergesa-gesa dalam membuat diagram pecahan.

3) Guru lebih aktif dalam membimbing siswa membuat diagram.

\section{Penutup}

Usaha perbaikan mutu pembelajaran dengan penggunaan Media Konversi Pecahan telah menghasilkan beberapa kesimpulan sebagai berikut:

1. Penggunakan Media Konversi Pecahan pada materi Pecahan di Kelas V SD Ngentak tahun pelajaran 2018/2019 ini dilaksanakan dalam dua siklus. 
2. Penggunaan Media Konversi Pecahan dapat meningkatkan hasil belajar kognitif siswa kelas V SD Ngentak tahun pelajaran 2018/2019. Data Peningkatan terjadi dari rata-rata 55 dan 47 saat penilaian akhir semester 1 menjadi 71 pada siklus 1 dan 87 pada siklus 2.

3. Penggunaan Media Konversi Pecahan dapat meningkatkan aktivitas siswa dalam belajar matematika. Hal ini terlihat berdasarkan pengamatan nilai rata-rata siklus 1 yaitu sebesar 8,5 dengan kategori cukup menjadi 10, 6 dengan kategori baik.

4. Penggunaan Media Konversi Pecahan dapat meningkatkan hasil belajar psikomotorik siswa. Hal ini terlihat berdasarkan pengamatan nilai rata-rata siklus 1 yaitu sebesar 8,5 dengan kategori cukup menjadi 10,0 dengan kategori baik.

\section{Ucapan Terima Kasih}

Penelitian dengan judul "Penerapan Media Konversi Pecahan untuk Meningkatkan Hasil Pembelajaran Matematika di Sekolah Dasar" telah selesai. Peneliti mengucapkan terima kasih kepada Kesharlindung Direktorat Pembinaan Guru Pendidikan Dasar atas kesempatan yang telah diberikan untuk perbaikan karya ini. Semoga Kesharlindung Direktorat Pembinaan Guru Pendidikan Dasar selalu diberikan kesuksesan dalam melayani masyarakat pendidikan Indonesia.

\section{DAFTAR PUSTAKA}

Abidin.Y, dkk. 2018. Pembelajaran Literasi: Strategi Meningkatkan Kemampuan Literasi Matematika, Sains, Membaca, dan Menulis. Jakarta: Bumi Aksara.

Daryanto. 2017. Pembelajaran Abad 21. Yogyakarta. Gava Media.

Dimyati, Mudjiono. 2013. Belajar \& Pembelajaran. Jakarta: Rineka Cipta.

Jauhar, M. 2011. Implementasi PAIKEM dari Behavioristik sampai Kontruktivistik: Sebuah Pengembangan Pembelajaran Berbasis 
CTL(Contextual Teaching \& Learning). Jakarta: Prestasi Pustakaraya.

Mahanani, A. 2018. Upaya Meningkatkan Hasil Belajar Matematika Materi Pecahan Sederhana melalui Media Kartu Pecahan di Kelas III SD Negeri 2 Wates. Yogyakarta: Universitas Negeri Yogyakarta.

Mardapi, D. 2012. Pengukuran, Penilaian dan Evaluasi Pendidikan. Yogyakarta: Nuha Litera.

Mulyasa, E. 2016. Guru dalam Implementasi Kurikulum 2013: Jadilah Guru Profesional atau Tidak Sama Sekali. Bandung: Rosda.

Permendikbud Tahun 2016 Nomor 21.

Rahayu, Y. 2018. Pengembangan Alat Peraga Papan Pelangi pada Operasi Hitung Pecahan di Sekolah Dasar. Jakarta: Jurnal Didaktika Pendidikan Dasar Vol 2 No. 2 Nopember 2018

Runtukahu.T, dkk. 2014. Pembelajaran Matematika Dasar bagi Anak Berkesulitan Belajar. Yogyakarta: Ar-Ruzz Media.

Sofiana. 2015. Peningkatan Hasil Belajar Operasi Hitung Bilangan Pecahan melalui Pendekatan Matematika Realistik pada Siswa SD Grenggeng. Yogyakarta. Universitas Negeri Yogyakarta.

Sudjana,dkk. 2010. Media Pengajaran. Bandung: Sinar Baru Algesindo Offset Bandung.

Suprijono, A. 2017. Cooperative Learning: Teori \& Aplikasi PAIKEM. Yogyakarta: Pustaka Pelajar.

Susilana,dkk. 2009. Media Pembelajaran: Hakikat, Pemanfaatan, dan Penilaian. Bandung: CV Wacana Prima.

Walid, A. 2017. Strategi Pembelajaran IPA. Yogyakarta. Pustaka Pelajar. 